\title{
INNOVATION OF DOCTORAL STUDIES AT THE FEM CULS PRAGUE
}

\begin{abstract}
Research results and university performance measures have been frequently discussed topic in the Czech higher education system. Performance can be improved by establishing innovations ineducationinmany areas. Athighereducation sector the performance within research activities is of the same importance. Various authorities have been making an effort to establish a set of measures to assess research performance at institutional level. This paper focuses on the assessment of research activity within an institution - Czech University of Life Sciences (CULS) Prague - with the use of Data Envelopment Analysis model (DEA). The measured units (DMUs) are 29 doctoral study specializations.

Based on the findings revealed by the DEA model application various measures adopted by the faculty in order to improve research and education performance are introduced. Following the widespread trend in many countries the focus of the effort is in training of university teachers and students. This aim is being partially accomplished by the Project Operational Program Prague Adaptability (OPPA), which is focused on the innovation of the $\mathrm{PhD}$ studies at the Faculty of Economics and Management. The main project aims are i) to improve students' research experiences, ii) to provide appropriate conditions for $\mathrm{PhD}$ students at the departments/faculty and iii) to launch tools for better communication among PhD students and their supervisors.
\end{abstract}

\section{Martin Flégl, Ivana Tichá,}

Lucie Kvasničková Stanislavská

Czech University of Life Sciences Prague

flegl@pef.czu.cz

ARTICLE INFO

Article type

Full research paper

doi: 10.7160/eriesj.2013.060405

Article history

Received: January 7, 2013

Received in revised form: October 21, 2012

Accepted: October 30, 2013

Available on-line: December 31, 2013

\section{Key Words}

DEA model, Education, Efficiency, Innovation, OPPA, PhD Student, Research and Development 


\section{Introduction}

With respect to the university outputs, university might attract more students if they innovate in a certain direction, or might influence the performance of their students by focussing on different innovations (Haelermans, Blank, 2012). According to the Commission of the European Communities (2003), there are three directions in which efforts aimed at improving quality in higher education should go:

1. Ensuring that European universities have sufficient and sustainable resources and use them efficiently

2. Consolidating excellence in teaching and in research

3. Opening up universities to a greater extent to the outside and increasing their international attractiveness

Universities' budgets face the declining support from the Czech government. As a result resources for innovations, i.e. innovations related to changes in teaching style, teaching facilities and teacher professionalization are limited. Universities should focus on the consolidation of excellence in teaching and in research.

Some innovations are visible to outsiders (for example new technical equipments in classrooms) and some of them are not (didactical approaches). During the adoption of new innovations it is important to take in consideration a mix of innovations and do not separate single innovations from the whole environment. For example Angrist and Lavy (2002) studied individual impact of IT innovations in education, Clotfelter et al. (2007) studied the impact of professionalization innovations.

An advantage of studying separate innovations is that its effect can be studied and, in the most situations, measured. However, ignoring the other innovations might over- or under-estimate its effect. Studying the mix of innovations represents better the reality of theeducational environment and the effecton university performance. Drucker (1985) defined innovation as the process of equipping in new, improved capabilities or increase utility. OECD Oslo Manual (2005) is the primary international basis of guidelines for defining and assessing innovation activities. This study distinguished four different innovation types. These are product innovation, process innovation, marketing innovation and organizational innovation. Following these types of innovation Haelermans and De Witte (2012) distinguished five innovation clusters in education:

1. New courses/profiling innovations

2. Pedagogical/didactical innovations

3. Process innovations

4. Professionalization of teachers' innovations

5. Education chain innovations

Innovations in the new courses/profiling cluster are related to the introduction of new courses (such as mathematics courses), to language innovations (bilingual education) and to the profile of school. Pedagogical/didactical innovations are mainly associated with the content of the courses and the way classes are taught. This cluster also includes the service for students as the development plan for the students. Process innovations relate to new buildings, IT structure etc ${ }^{1}$. Professionalization of teachers innovations include all innovations that are related to the teaching staff. And finally education chain innovations mainly refer to innovations arising from collaborations between the

Not all of the process innovations might have a positive impact on students' performance. The reason of negative impact is that money available for IT can be spend on other purpose. 
secondary schools, elementary schools, universities or business companies ${ }^{2}$. Haelermans and De Witte (2012) also show that, on average, the most innovations are made in pedagogical area.

This paper focuses on the improvement of research performance of the Faculty of Economics and Management through enhancement of the quality of $\mathrm{PhD}$ studies. For this purpose the pedagogical/didactical and professionalization innovation clusters seem to be the most suitable.

There are a few studies regarding the effect of pedagogical innovations on educational performance. For example Nii and Chin (1996) found that problem-based learning ${ }^{3}$ leads to higher grades than using traditional didactic lecturing. Fuchs and Woessmann (2007) observed that teachers experimenting with pedagogic approaches obtain higher students achievement with their students. Queen (2009) pointed out that cooperative learning significantly benefits student more than traditional instruction. The way of teaching influences

$\underline{2} \quad$ We may find some connections between OECD Oslo Manual (2005) innovation types and Haelermans and De Witte (2012) clusters. Process innovation is the implementation of a new or significantly improved production or delivery method. This includes significant changes in techniques, equipment and/or software. Process innovation also leads to increasing quality itself. Compare to educational innovation clusters, this innovation type includes Course/profiling, Pedagogical/didactical and Process innovations clusters. Organizational innovation is the implementation of a new organizational method in the firm's business practices, workplace organization or external relations. Organizational innovations have tendency to increase firm performance by reducing administrative and transaction costs, improving workplace satisfaction (labour productivity). This type corresponds with Professionalization of teachers cluster.

3 Problem-based learning (PBL) is a system of teaching which gives student knowledge through an active learning process. This process is believed to be better than other systems learned through conventional passive rote methods. The major advantage of PBL is the development of an effective, readily accessible knowledge base that is store in long-term memory (Nii and Chin, 1996). the innovativeness of a school, because it partly reflects the willingness to change. Furthermore, literature has shown that teacher characteristics influence innovativeness and student performance (Haelermans, Blank, 2012, Könings et al., 2007).

On the other hand, it must be taken into consideration that continuous changes in pedagogy might confuse the students and make the performance worse instead of better. Könings et al. (2007) also emphasised that students might be overloaded with too many work in the new environment. Educators must be more student-centred oriented instead of self-centred oriented (Postareff et al., 2007). Focus of the student-centred teaching is more on the students and their learning, rather than on teacher. This kind of teaching is about facilitating student's learning. Students are encouraged to construct their own knowledge and understanding and to strive towards becoming and independent learner. In this case, students should face self-audit questionnaires to realise their strong and weak skills according to their independency.

Second cluster, mentioned above, is professionalization. This cluster includes all innovations related to teachers, in the context of $\mathrm{PhD}$ studies - supervisor. Teachers are a central factor in the learning process, but in many countries teacher profession is not very attractive, mainly due to the lower average of the salaries. Many studies (Atkinson et al., 2009, Kingdom and Teal, 2007 and Lavy, 2009) describe the relation among the approach for teacher pay, teacher quality or teacher training (teacher pay is typically based on teacher experience and education level). From the studies it is evident that higher salaries motivate higher teacher effort and, following the Atkinson et al. (2009) suggestion, educational authorities should consider that 
teacher-based performance pay is a policy tool that education authorities should consider as part of their drive to raise educational performance ${ }^{4}$.

Willingness is the crucial factor for implementing new educational innovations. Abrami et al. (2004) pointed out that teachers need to believe that they have skills for implementing the innovations and it will positively influence their working environment. Van Eekelen (2005) divided teachers into three groups according to their willingness for the new innovations:

1. Teachers who do not see why there is a need to learn and hold on to old teaching habits, do not have open minds for others, are not very critical of their own role in education and seldom reflect or ask themselves questions.

2. Teachers who wonder how to learn and want to improve their teaching practices, but do not know how to accomplish this. They are mostly critical of their own role and are not open to the others.

3. Teachers who are eager to learn and want to improve their performances and undertake action in order to learn. They have an open mind for others and are critical towards their own role.

The lack of communication between innovation designers and teachers is the reason of many innovative failures (Staub, 2004). Teacher professionalization innovations are closely related with school/university and student performance (Clotfelter et al., 2007, Könings et al., 2007). The effect of teacher quality, experience of teachers and the education of teachers have big influence on student performance (Postareff et al., 2007, Gibbs

\footnotetext{
4 In case of the FEM CULS Prague, teacher's effort can be motivated through motivation program (FEM, 2010). This program was introduced in 2010 and the main purpose is to stimulate teacher's performance via publication and research activity. Higher performance leads to the higher teacher pay.
}

and Coffey, 2004). Teacher quality can be improved. Buddin and Zamarro (2009) agreed with teachers' influence, but their research, on the other side, shows that the influence is difficult to measure and research evidence provides little indication how teacher quality can be enhanced.

The main objective of this paper is to assess research efficiency of doctoral studies in all accredited specializations delivered at Czech University of Life Sciences Prague with the use of Data Envelopment Analysis (DEA). Model works with publications and research activity as key measures. Specializations of doctoral studies at the Faculty of Economics and Management are in the main focus. Based on this assessment various measures adopted to enhance the research activity and improve its crucial part - PhD studies - are described with the focus on Operational Program Prague - Adaptability (OPPA) project aiming at the quality improvement of PhD studies at the Faculty of Economics and Management.

\section{Material and Methods}

\section{Doctoral study programmes at CULS Prague}

Doctoral study programmes are the third level studies at the all CULS Prague faculties, i.e. Faculty of Economics and Management (FEM), Faculty of Agrobiology, Food and Natural Resources (FAFNR), Faculty of Engineering (FE), Faculty of Environmental Sciences (FES), Faculty of Forestry and Wood Sciences (FFWS), and Faculty of Tropical AgriSciences (FTAS). For the organization, administration and control of the studies the deans or vice-deans of each faculty are responsible. (CULS, 2012)

Studies in the Doctoral Study Programme (DSP) are intended for university graduates who completed their studies with a required state examination in a field ensued by the DSP or 
in a field closely related. The basic aim of the DSP is to obtain and demonstrate the ability of independent research work in a particular scientific field by carrying out and defending doctoral dissertation, publications and other forms of presenting own scientific-research activities, including completing all required exams and the State Doctoral Exam. The DSP graduates receive an academic-scientific title "Doctor" (abbreviated as PhD behind the name). Students are enrolled into the studies on the basis of a positive result of entrance examination.

The studies are organised in two forms - full time and part time. The full time study form is the main form of the doctoral studies and also main source of income of the PhD student. Students in the full time form have the status of university students and in the course of their studies they are monthly paid a doctoral scholarship. The part time form is intended for working graduates or the members of faculty staff who during the studies remain in their occupations.

Czech University of Life Sciences Prague provides, in total, 18 study programmes in 29 specializations (CULS, 2011) (see Table 1). Faculty of Economics and Management provides doctoral studies in 4 study programmes with 5 specializations (FEM, 2012). In these study programmes, $1084 \mathrm{PhD}$ students were enrolled in the year 2011 .

\begin{tabular}{|l|l|l|l|}
\hline \multicolumn{1}{|c|}{ Code } & \multicolumn{1}{c|}{$\begin{array}{c}\text { Study } \\
\text { programme }\end{array}$} & \multicolumn{1}{c|}{ Specialization } & Faculty \\
\hline FAFNR-GCS & Crop Science & General Crop Science & FAFNR \\
\hline FAFNR-SCS & Crop Science & Special Crop Science & FAFNR \\
\hline FAFNR-GAS & Animal Science & General Animal Science & FAFNR \\
\hline FAFNR-SAS & Animal Science & Special Animal Science & FAFNR \\
\hline
\end{tabular}

\begin{tabular}{|c|c|c|c|}
\hline Code & $\begin{array}{c}\text { Study } \\
\text { programme }\end{array}$ & Specialization & Faculty \\
\hline FAFNR-AFPPP & $\begin{array}{l}\text { Agricultural } \\
\text { Specialisation }\end{array}$ & $\begin{array}{l}\text { Agricultural and Forestry } \\
\text { Phytopathology and Plant } \\
\text { Protection }\end{array}$ & FAFNR \\
\hline FAFNR-ACH & $\begin{array}{l}\text { Agricultural } \\
\text { Specialisation }\end{array}$ & Agricultural Chemistry & FAFNR \\
\hline FAFNR-ECNR & $\begin{array}{l}\text { Agricultural } \\
\text { Specialisation }\end{array}$ & $\begin{array}{l}\text { Exploitation and Conversation of } \\
\text { Natural Resources }\end{array}$ & FAFNR \\
\hline FE-PE & $\begin{array}{l}\text { Power } \\
\text { Engineering }\end{array}$ & Power Engineering & $\mathrm{FE}$ \\
\hline FE-QDME & $\begin{array}{l}\text { Special } \\
\text { Technologies }\end{array}$ & $\begin{array}{l}\text { Quality and Dependability of } \\
\text { Machines and Equipment }\end{array}$ & FE \\
\hline FE-EATS & $\begin{array}{l}\text { Agricultural } \\
\text { Engineering }\end{array}$ & $\begin{array}{l}\text { Engineering of Agricultural } \\
\text { Technological Systems }\end{array}$ & FE \\
\hline FE-TPP & $\begin{array}{l}\text { Agricultural } \\
\text { Engineering }\end{array}$ & $\begin{array}{l}\text { Technology of Production } \\
\text { Processes }\end{array}$ & $\mathrm{FE}$ \\
\hline FE-MMTS & $\begin{array}{l}\text { Agricultural } \\
\text { Specialisation }\end{array}$ & $\begin{array}{l}\text { Marketing of Machines and } \\
\text { Technical Systems }\end{array}$ & FE \\
\hline FEM-SEEE & $\begin{array}{l}\text { Economics and } \\
\text { Management }\end{array}$ & $\begin{array}{l}\text { Sector Economics and Economics } \\
\text { of Enterprise }\end{array}$ & FEM \\
\hline FEM-M & $\begin{array}{l}\text { Economics and } \\
\text { Management }\end{array}$ & Management & FEM \\
\hline FEM-RSD & $\begin{array}{l}\text { Economic } \\
\text { Policy and } \\
\text { Administration }\end{array}$ & Regional and Social Development & FEM \\
\hline FEM-IM & $\begin{array}{l}\text { Systems } \\
\text { Engineering } \\
\text { and Statistics } \\
\end{array}$ & Information Management & FEM \\
\hline FEM-SE & $\begin{array}{l}\text { Quantitative } \\
\text { Methods } \\
\text { in Economics }\end{array}$ & Systems Engineering & FEM \\
\hline FES-ALE & $\begin{array}{l}\text { Applied } \\
\text { Ecology }\end{array}$ & Applied and Landscape Ecology & FES \\
\hline FES-E & Ecology & Ecology & FES \\
\hline
\end{tabular}




\begin{tabular}{|l|l|l|c|}
\hline \multicolumn{1}{|c|}{ Code } & \multicolumn{1}{|c|}{$\begin{array}{c}\text { Study } \\
\text { programme }\end{array}$} & \multicolumn{1}{c|}{ Specialization } & Faculty \\
\hline FES-EM & $\begin{array}{l}\text { Landscape } \\
\text { Engineering }\end{array}$ & Environmental Modelling & FES \\
\hline FES-WRIL & $\begin{array}{l}\text { Landscape } \\
\text { Engineering }\end{array}$ & $\begin{array}{l}\text { Water Regime Improvement in } \\
\text { Landscape }\end{array}$ & FES \\
\hline FFWS-DFTB & Forestry & $\begin{array}{l}\text { Dendrology and Forest Tree } \\
\text { Breeding }\end{array}$ & FFWS \\
\hline FFWS-FM & Forestry & Forest Management & FFWS \\
\hline FFWS-FPGM & Forestry & $\begin{array}{l}\text { Forest Protection and Game } \\
\text { Management }\end{array}$ & FFWS \\
\hline FFWS-TMF & Forestry & $\begin{array}{l}\text { Technology and Mechanisation in } \\
\text { Forestry }\end{array}$ & FFWS \\
\hline FFWS-S & $\begin{array}{l}\text { Forestry } \\
\text { Engineering }\end{array}$ & Silviculture & FFWS \\
\hline FFWS-EME & $\begin{array}{l}\text { Economics and } \\
\text { Management }\end{array}$ & $\begin{array}{l}\text { Economics and Management of } \\
\text { an Enterprise }\end{array}$ & FFWS \\
\hline FTAS-TSA & $\begin{array}{l}\text { Agricultural } \\
\text { Specialisation }\end{array}$ & $\begin{array}{l}\text { Tropical and Subtropical } \\
\text { Agriculture }\end{array}$ & FTAS \\
\hline FTAS-SRD & $\begin{array}{l}\text { Agricultural } \\
\text { Specialisation }\end{array}$ & Sustainable Rural Development & FTAS \\
\hline
\end{tabular}

Table 1: Doctoral study programmes/specializations at CULS Prague, 2011

\section{Evaluation of the R\&D results}

The study builds on secondary data. The source of the data is Rejstřík informací o výsledcích/Information Register of R\&D results (RIV), which is the key database for the evaluation of scientific work in the Czech Republic. The evaluation is carried out by the Rada pro výzkum, vývoj a inovace/Research, Development and Innovation Council (RVVI). All the results are evaluated by the Metodika hodnocení výsledků výzkumných organizací/Methods for evaluating R\&D results (RVVI 2010), which are focused on results that were produced by each research organisation in the last five years. The model is based on the data files that refer to R\&D results published between 2007 and 2011. These results were officially published by the Council in January 2012.

The official evaluation process is based on formalised procedures. Methods distinguish between two categories of results: (1) results of the basic research - books, papers in scientific journals, conference proceedings and (2) results of applied research - patents, prototypes, industrial designs, maps, certified methods, and software. Each of these results is ascribed a score, such as 20 points for a book, a paper in a journal of the impact factor (IF) receives a score within the interval 10 - 305 (according to the journal ranking), and certified methods approved by a State administration body are valued at 40 points, etc. The evaluation is carried out for each organisation (such as a university), whereby the organisation gains the relative share equal to the share of the authors who created the outcome and are affiliated to the given organisation.

The methods for evaluation are intensively discussed within the field of scientific policy. The main goal of evaluation is to provide information on research results that were created with financial support from public resources, and also to gain an insight into the efficiency of such financing. The quantitative evaluation of the organisation has direct implications for financing universities, research organisations and others. From this point of view, the achieved scores indicate the scientific productivity of the organisation. Despite the fact that the official evaluation has many weaknesses, a different tool is not available to enable $R \& D$ results to be quantitatively evaluated on the same level of exactness and complexity as the current system. 
During the last years FEM increased its publication results. Even though RIV points had been increasing from 2076 points in 2004-2008 (RIV 5-year evaluation period) to 7067 points in 2007-2011, the RIV result is well behind in comparison with to the other faculties. In addition, the result of FEM means only $12.3 \%$ of the CULS Prague results in 2007-2011. All the RIV results for the whole CULS Prague are summarised in Table 2.

\begin{tabular}{|c|c|c|c|c|}
\hline & $2004-2008$ & $2005-2009$ & $2006-2010$ & $2007-2011$ \\
\hline FAFNR & 9988.049 & 13816.031 & 16525.915 & 17998.27 \\
\hline FE & 1550.176 & 3353.964 & 4743.02 & 6603.371 \\
\hline FEM & 2076.001 & 3603.735 & 5275.951 & 7067.175 \\
\hline FES & 1861.476 & 4108.694 & 6654.638 & 10981.04 \\
\hline FFWS & 2454.73 & 3900.72 & 4738.734 & 9634.84 \\
\hline FTAS & 486.42 & 1075.96 & 1238.189 & 1386.123 \\
\hline CULS & 18416.852 & 29859.104 & 39176.447 & 53670.82 \\
\hline
\end{tabular}

Table 2: Number of RIV points, CULS Prague, 2004-2011

\section{Background Data}

Background data for the DEA model contains Decision Making Units (DMUs), 2 inputs and 3 outputs (Table 3). Evaluated DMUs are expressed for 29 specializations at CULS Prague (specializations abbreviations correspond with codes mentioned in Table 1). Input 1 refers to a number of PhD students in each specialization. Input 2 provides information about an average length of study in years in each specialization.

Outputs of the DEA model then refers to: Output 1 express a number of graduated $\mathrm{PhD}$ students in each specialization, Output 2 refers to research quality including R\&D points that were collected by PhD students in the 2007 - 2011 period and, finally, Output 3 express a proportion between number of graduated $\mathrm{PhD}$ students to a number of $\mathrm{PhD}$ supervisors. The last output should indicate to a quality of each doctoral study field, i.e. if PhD supervisors are able to produce sufficient number of graduated $\mathrm{PhD}$ students.

The data were obtained, except $R \& D$ points, from the university's databases during the period of 2007 - 2011.

Specialization FTAS-SRD is excluded from the efficiency evaluation because this specialization started only 2 years ago. $\mathrm{PhD}$ students have not had sufficient time to obtain many RIV points. Therefore, its efficiency score would inappropriately influence the DEA model.

\begin{tabular}{|l|c|c|c|c|c|}
\hline \multicolumn{1}{|c|}{ DMU } & Input 1 & Input 2 & Output 1 & Output 2 & Output 3 \\
\hline FAFNR-GCS & 32 & 4.297 & 17 & 149.584 & 1.889 \\
\hline FAFNR-SCS & 46 & 4.450 & 10 & 178.0474 & 0.714 \\
\hline FAFNR-GAS & 68 & 3.838 & 6 & 339.56 & 0.300 \\
\hline FAFNR-SAS & 26 & 4.145 & 9 & 109.5405 & 1.125 \\
\hline $\begin{array}{l}\text { FAFNR- } \\
\text { AFPPP }\end{array}$ & 19 & 4.508 & 10 & 123.1765 & 5.000 \\
\hline FAFNR-ACH & 10 & 3.419 & 1 & 220.191 & 0.333 \\
\hline FAFNR-ECNR & 20 & 3.192 & 0 & 197.6853 & 0.000 \\
\hline FE-PE & 22 & 4.319 & 2 & 322.5452 & 0.286 \\
\hline FE-QDME & 34 & 3.672 & 2 & 163.6357 & 0.400 \\
\hline FE-EATS & 19 & 3.993 & 1 & 124.8187 & 0.125 \\
\hline FE-TPP & 27 & 4.167 & 3 & 237.6103 & 0.375 \\
\hline FE-MMTS & 8 & 3.500 & 3 & 21.258 & 1.500 \\
\hline FEM-SEEE & 86 & 3.794 & 8 & 106.4948 & 0.308 \\
\hline
\end{tabular}




\begin{tabular}{|l|c|c|c|c|c|}
\hline \multicolumn{1}{|c|}{ DMU } & Input 1 & Input 2 & Output 1 & Output 2 & Output 3 \\
\hline FEM-M & 46 & 3.368 & 7 & 250.306 & 0.636 \\
\hline FEM-RSD & 33 & 3.306 & 5 & 228.5746 & 0.500 \\
\hline FEM-IM & 36 & 3.580 & 9 & 377.9208 & 0.900 \\
\hline FEM-SE & 23 & 3.730 & 4 & 168.2817 & 0.143 \\
\hline FES-ALE & 93 & 3.479 & 1 & 1664.676 & 0.059 \\
\hline FES-E & 51 & 4.125 & 5 & 277.8022 & 0.556 \\
\hline FES-EM & 39 & 3.939 & 2 & 150.0518 & 2.000 \\
\hline FES-WRIL & 25 & 4.071 & 1 & 158.5419 & 0.143 \\
\hline FFWS-DFTB & 10 & 3.333 & 4 & 11.2955 & 0.667 \\
\hline FFWS-FM & 19 & 3.645 & 0 & 313.8497 & 0.000 \\
\hline FFWS-FPGM & 56 & 4.148 & 1 & 758.4537 & 0.071 \\
\hline FFWS-TMF & 29 & 3.489 & 1 & 168.0415 & 0.167 \\
\hline FFWS-S & 42 & 4.071 & 1 & 343.5769 & 0.167 \\
\hline FFWS-EME & 45 & 3.487 & 1 & 67.2092 & 0.167 \\
\hline FTAS-TSA & 98 & 4.144 & 9 & 216.5962 & 0.692 \\
\hline FTAS-SRD & 22 & 2.955 & 0 & 1.2755 & 0.000 \\
\hline
\end{tabular}

Table 3: Structure and input data of DEA model

\section{Data Envelopment Analysis Method}

Data Envelopment Analysis (DEA) evaluates decision-making units (DMUs) against the best DMUs with the idea that: if one DMU can produce a certain level of output utilising a certain level of input, another DMU of equal scale should be capable of doing relatively the same. DEA is a non-linear programming model for the estimation of productive efficiency of DMUs, based on the relationship between multiple outputs and multiple inputs. These outputs and inputs are usually of various characteristics and of a variety of forms which are difficult to measure. The DEA measure of the efficiency of any DMU is obtained as the maximum of a ratio of weighted outputs to weighted inputs, subject to the condition that the similar ratio for every DMU is less than or equal to 1 .

The simplest DEA model assumes constant returns to scale, this model is called the CCR model, according to its authors, Charnes, Cooper, and Rhodes (1978). Let $y_{j k}$ be the amount of the $j^{\text {th }}$ output from unit $k$, and $x_{i k}$ be the amount of the $i^{\text {th }}$ input to the $k^{\text {th }}$ unit. Using the CCR model, the DMU efficiency of a particular unit $H$ is calculated using the following linearisation of the original DEA model. Primal and dual CCR output oriented models are formulated as:

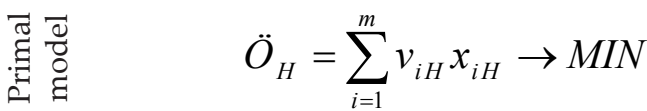

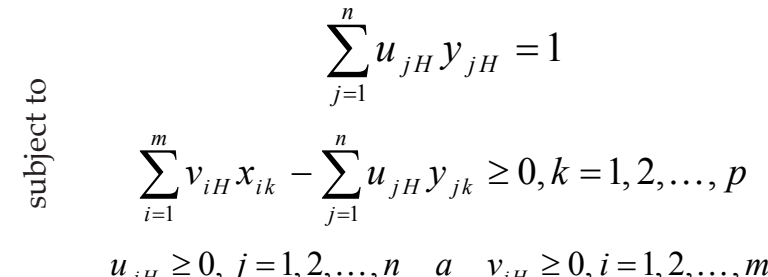




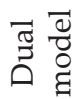

$$
\begin{aligned}
& \sum_{k=1}^{p} \lambda_{k H} x_{k} \leq x_{i H}, i=1,2, \ldots, m
\end{aligned}
$$

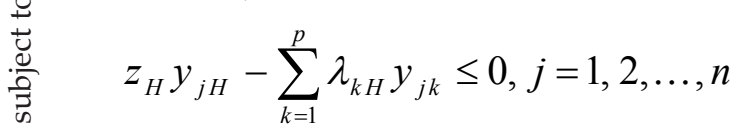

$$
\begin{aligned}
& \lambda_{k H} \geq 0, k=1,2, \ldots, p
\end{aligned}
$$

The decision variables $u=\left(u_{1}, \ldots, u_{m}\right)$ and $v=\left(v_{1}, \ldots, v_{n}\right)$ are the weights given to the $\mathrm{m}$ outputs and to the $\mathrm{n}$ inputs respectively. To obtain the relative efficiencies of all the units, the model is solved for one unit at a time. The decision variables $\lambda=\left(\lambda_{1^{\prime}}, \ldots, \lambda_{p}\right)$ are the weights given to the efficient DMUs for creating virtual (efficient) DMU corresponding to non- efficient DMU. Inputs and outputs of virtual DMU are calculated using the formulas

$$
\begin{aligned}
& x_{i H}^{\prime}=\ddot{O}_{H} x_{H}-s_{i H}^{-}, \quad i=1, \ldots, m \\
& y_{j H}^{\prime}=y_{j H}+s_{j H}{ }^{+}, \quad j=1, \ldots, n \\
& x_{i H}^{\prime}=\sum_{k=1}^{p} \lambda_{k H} x_{k}, \quad i=1, \ldots, m \\
& y_{j H}^{\prime}=\sum_{k=1}^{p} \lambda_{k H} y_{j k}, \quad j=1, \ldots, n
\end{aligned}
$$$$
\text { or }
$$

where $S_{i H}^{-}$a $S_{j H}^{+}$are slacks in the dual constraints.
Output orientation of the model means that results explicitly show the necessary augmentation of outputs with the same amount of inputs. Authors used Efficiency Measurement System (EMS) SW for calculation of the DEA model (Scheel, 2000).

\section{Results and Discussion}

DEA models can be calculated with an input or output orientation. In our contribution, the DEA model is outputoriented. The reason for output orientation is due to the objectives of this work, i.e. assess the research efficiency of the doctoral studies. Recommendation for an inefficient specialization is an improvement of the publication/research activities, and/ or increase a number of graduated $\mathrm{PhD}$ student. Authors also assume the constant returns to scale and radial measure for outputs. More PhD students and longer average length of study (with well supervised PhD students) should lead to more $R \& D$ and to more graduated students. It is also necessary to mention that this model reflects conditions in the year 2011. Table 4 summarises the efficiency results of the specializations. Efficient specialization reached the efficiency result of $100 \%$, i.e. regarding to their inputs produced a sufficient amount of outputs (publication/research points and graduated $\mathrm{PhD}$ students). Efficient specializations are General Crop Science (FAFNR-GCS), Agricultural and Forestry Phytopathology and Plant Protection (FAFNR-AFPPP) and Agricultural Chemistry (FAFNR-ACH) from Faculty of Agrobiology, Food and Natural Resources, and also Applied and Landscape Ecology (FES-ALE) from Faculty of Environmental Sciences.

One of the main objectives was to focus especially on the efficiency results of doctoral studies at FEM., which all are inefficient. An average efficiency of a specialization at FEM is $157.80 \%$ (see Table 5). This level does not put doctoral studies 
at FEM to significantly inefficient position, however, none specializations at Faculty of Economics and Management reached the efficient frontier. From this reason, an improvement should be considered. In order to achieve efficient level, the specializations should produce 3.5 graduated $\mathrm{PhD}$ students more. This will lead to an improvement of proportion between graduate $\mathrm{PhD}$ students and $\mathrm{PhD}$ supervisors. In addition, $\mathrm{PhD}$ students should produce $109 \mathrm{R} \& \mathrm{D}$ points more. It is also necessary to note that differences between doctoral study fields at FEM exist.

\begin{tabular}{|c|c|c|c|c|c|c|c|}
\hline 导 & 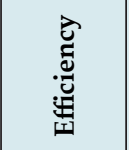 & 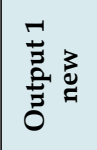 & 苞 & 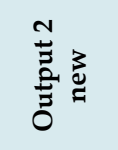 & 苞 & 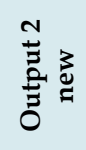 & 芯 \\
\hline FAFNR-GCS & $100.00 \%$ & 17.000 & - & 149.584 & - & 1.889 & - \\
\hline $\begin{array}{c}\text { FAFNR- } \\
\text { SCS }\end{array}$ & $164.61 \%$ & 16.461 & 6.461 & 293.084 & 115.036 & 1.826 & 1.112 \\
\hline FAFNR-GAS & $184.94 \%$ & 11.096 & 5.096 & 627.982 & 288.422 & 1.215 & 0.915 \\
\hline FAFNR-SAS & $144.49 \%$ & 13.004 & 4.004 & 158.275 & 48.735 & 2.026 & 0.901 \\
\hline $\begin{array}{l}\text { FAFNR- } \\
\text { AFPPP }\end{array}$ & $100.00 \%$ & 10.000 & - & 123.177 & - & 5.000 & - \\
\hline $\begin{array}{c}\text { FAFNR- } \\
\text { ACH }\end{array}$ & $100.00 \%$ & 1.000 & - & 220.191 & - & 0.333 & - \\
\hline $\begin{array}{c}\text { FAFNR- } \\
\text { ECNR }\end{array}$ & $197.82 \%$ & 0.930 & 0.930 & 391.061 & 193.376 & 0.280 & 0.280 \\
\hline FE-PE & $125.34 \%$ & 2.507 & 0.507 & 404.278 & 81.733 & 0.508 & 0.222 \\
\hline FE-QDME & $301.39 \%$ & 6.028 & 4.028 & 493.182 & 329.546 & 1.206 & 0.806 \\
\hline FE-EATS & $271.41 \%$ & 2.714 & 1.714 & 338.770 & 213.952 & 0.519 & 0.394 \\
\hline FE-TPP & $172.24 \%$ & 5.167 & 2.167 & 409.260 & 171.650 & 0.746 & 0.371 \\
\hline
\end{tabular}

\begin{tabular}{|c|c|c|c|c|c|c|c|}
\hline FE-MMTS & $140.35 \%$ & 4.211 & 1.211 & 51.866 & 30.608 & 2.105 & 0.605 \\
\hline FEM-SEEE & $181.30 \%$ & 14.504 & 6.504 & 193.075 & 86.580 & 1.608 & 1.300 \\
\hline FEM-M & $157.62 \%$ & 11.033 & 4.033 & 394.532 & 144.226 & 1.213 & 0.577 \\
\hline FEM-RSD & $171.99 \%$ & 8.600 & 3.600 & 393.125 & 164.551 & 0.990 & 0.490 \\
\hline FEM-IM & $109.57 \%$ & 9.861 & 0.861 & 414.088 & 36.167 & 1.126 & 0.226 \\
\hline FEM-SE & $168.51 \%$ & 6.740 & 2.740 & 283.571 & 115.290 & 0.871 & 0.728 \\
\hline FES-ALE & $100.00 \%$ & 1.000 & - & 1664.676 & - & 0.059 & - \\
\hline FES-E & $229.91 \%$ & 11.496 & 6.496 & 638.695 & 360.893 & 1.277 & 0.722 \\
\hline FES-EM & $195.89 \%$ & 7.938 & 5.938 & 293.936 & 143.885 & 3.918 & 1.918 \\
\hline FES-WRIL & $279.13 \%$ & 2.791 & 1.791 & 442.538 & 283.996 & 0.509 & 0.366 \\
\hline FFWS-DFTB & $132.63 \%$ & 5.305 & 1.305 & 49.351 & 38.056 & 0.884 & 0.218 \\
\hline FFWS-FM & $121.01 \%$ & 1.060 & 1.060 & 379.790 & 65.940 & 0.330 & 0.330 \\
\hline FFWS-FPGM & $135.25 \%$ & 1.353 & 0.353 & 1025.809 & 267.355 & 0.267 & 0.195 \\
\hline FFWS-TMF & $294.34 \%$ & 2.943 & 1.943 & 494.613 & 326.572 & 0.491 & 0.324 \\
\hline FFWS-S & $219.93 \%$ & 2.199 & 1.199 & 755.629 & 412.052 & 0.397 & 0.230 \\
\hline FFWS-EME & $883.28 \%$ & 8.833 & 7.833 & 593.645 & 526.436 & 1.472 & 1.305 \\
\hline FTAS-TSA & $163.00 \%$ & 14.670 & 5.670 & 353.052 & 136.456 & 1.618 & 0.926 \\
\hline
\end{tabular}

Table 4: Doctoral study fields efficiency and new values for outputs 


\begin{tabular}{|l|c|c|c|c|}
\hline Faculty & $\begin{array}{c}\text { Average } \\
\text { efficiency }\end{array}$ & $\begin{array}{c}\text { Output 1 } \\
\text { average } \\
\text { improvement }\end{array}$ & $\begin{array}{c}\text { Output 2 average } \\
\text { improvement }\end{array}$ & $\begin{array}{c}\text { Output 3 average } \\
\text { improvement }\end{array}$ \\
\hline FAFNR & $141.69 \%$ & 2.356 & 92.224 & 0.458 \\
\hline FE & $202.15 \%$ & 1.925 & 165.498 & 0.480 \\
\hline FEM & $157.80 \%$ & 3.548 & 109.363 & 0.664 \\
\hline FES & $201.23 \%$ & 3.556 & 197.193 & 0.751 \\
\hline FFWS & $297.74 \%$ & 2.282 & 272.735 & 0.434 \\
\hline FTAS & $163.00 \%$ & 5.670 & 136.456 & 0.926 \\
\hline
\end{tabular}

Table 5: Comparison between faculties and proposed improvement

\section{Discussion}

Recalculated inefficient results also show us, which specialiazation should consider improvement of their $\mathrm{PhD}$ students' performance. For example FEM-SEEE had $86 \mathrm{PhD}$ students in 2011, but at the same time only 8 students graduated. If the length of the study 4 years is considered, the efficient number of graduates is around 20 graduated PhD students. With natural failures taken into account, the proposed improvement by DEA model is 6 more graduated PhD students.

In addition, FEM-RSD should increase the research performance by 164.55 points. This proposed improvement would lead to an increased efficiency by $50 \%$. The most efficient specialization at Faculty of Economics and Management is FEM-IM. The proposed improvement suggests less than 1 graduated PhD student and approximately $36 \mathrm{R} \& \mathrm{D}$ points - this is not that significant.
Reason for the insufficient research results at Faculty of Economics and Management can be explained with a poor quality of the students' research experience, inappropriate conditions for $\mathrm{Ph}$. students at the departments/faculty (low scholarship, department's environment, etc.) and low communication among PhD students and their supervisors. These are the main factors that lead to failures to complete doctoral studies. $^{5}$

From the reason of the unsatisfied performance, project for Innovation of the doctoral study program (IDSP) was lunched at the FEM CULS Prague in March 2012. This project is financed from European Social Funds (ESF) and OPPA program. Program OPPA has together 3 areas (OPPA, 2012) and the project was submitted in Priority axis 3 (modernization of the initial education). Beneficiaries in the Priority axis 3 include students, pedagogical staff, academic staff and those who left the educational system prematurely. Eligible applicants are schools, public institutions and non-governmental organizations (NGOs). Approximately $29 \%$ of the all financial resources in OPPA, i.e. 37188301 EUR are reserved for the modernization of the initial education. All the terms and conditions always regulate a particular call (OPPA, 2009).

The priority axis 3 supports development and innovation of the study programs at schools/universities. Tools how to achieve such development in the study programs include launching

\footnotetext{
5 Kadeřábková, T., Pokorná, J., Ǩezníčková, K. (2008) 'Zpráva o doktorském studiu na ČZU - dotazníkové šetření/Report on doctoral studies at CULS Prague questionnaire survey', CULS Prague, unpublished internal document.
} 
of new modern methods in education, new study subjects, teachers' education and also a support of the technical study programs.

Project IDSP has been submitted in the operational program CZ.2.17 Prague - Adaptability (CZ.2.17 Praha - Adaptabilita), Priority axis 3 Modernization of the initial education (Modernizace počátečního vzdělávání), number of the call: 04, under the group of the activities B. - Development and innovation of the bachelor and doctoral study programs at the universities (Rozvoj a inovace bakalářských a doktorských studijních programů na vysokých školách). (Call, 2011)

The project includes several parts/activities. All these parts focus on improvement of the R\&D performance, mainly on PhD students and partly on PhD supervisors. The project parts are following:

\section{Methodological workshops for PhD students}

Eight hands-on experience workshops aimed development of students' skill in social research methods and techniques will be organized within the project. Both international and Czech experts will deliver the workshops. Every newly enrolled PhD student will attend obligatory methodological seminar at the beginning of his/her study. They will also have a chance to attend another one or two workshops (up to their choice) during the academic year. During each academic year 4 different workshops (two during the winter semester and two during the summer semester) will be organized. Each workshop is planned for maximum of the 25 students.

\section{Workshop for PhD supervisors}

This activity is directly aimed on the increasing of knowledge and skills of the $\mathrm{PhD}$ supervisors with the aim to enhance quality and efficiency of education and learning. This kind of the competences have not been developed at all, despite that the supervisor plays the key role in the learning process of each $\mathrm{PhD}$ student. Due to the fact that there are not many courses and lectures in this area, the lectures from abroad will be invited. Workshop is basically prepared for academic staff who has become new supervisor or to those who are going to be new supervisors in the near future.

\section{Induction Week}

The opening program "Induction week" is a newly developed part of the doctoral study. This special workshop would make the transfer from the master study to the doctoral study smoother and each new PhD student would be able to get basic orientation at the FEM. Activities leading to the introduction of newly enrolled PhD students to the doctoral study, to the research and development infrastructure, to grant policy on all the relevant levels, to actual research and development activity at the Faculty and to the basic principles of the scientific work and administrative formalities of the study are combined within Induction week.

\section{Vademecum - individual plan of PhD student's development}

Individual plan of development is a new electronic methodological tool that should help to gain the maximal potential of the doctoral studies. The main purpose of this tool is effectively support the professional growth of all $\mathrm{PhD}$ 
students. This growth can be achieved due to the increasing of the educational quality and preparation for future academic career.

Methodical instructions will be aimed towards the strengthening of student interest in directing their own professional orientation, taking a major share of the responsibility for their own professional development, while ensuring that with regard to regular review and self-assessment to monitor and adjust the content and form of activities related to doctoral studies.

\section{Interactive electronic storage - Vibe}

Electronic tool Vademecum is connected with document storage Vibe. Vibe is the last part of the project and it is the key activity. Vibe is used as a knowledge base for effective knowledge sharing among different user groups influencing doctoral studies at FEM. The success of this methodical tool will mainly depend on $\mathrm{PhD}$ students and their cooperation with their supervisors and workshop leaders. Vibe allows $\mathrm{PhD}$ students to store their documents related to their professional growth and personal development in a central storage and, by controlled way, access already stored files.

All the project activities (methodological workshops, improve communication among PhD students and supervisors, etc.) are designed to have a positive impact on the research performance and thus to a higher number of graduated $\mathrm{PhD}$ students.

Although IDSP project is a specific project for FEM, we can find many similar projects at the other Czech universities and their faculties. For example project Innovation of doctoral study at the Faculty of Informatics at Masaryk University (FI MUNI, 2012). Project includes innovations in new contain of the courses, workshops with foreign lecturers and new motivation program for PhD students. Another innovative project was lunched at the Faculty of Social Science at Charles University (FSS CU, 2012). Project aims on developing new PhD courses that would allow better transitions between doctoral programs and courses and increase Interdisciplinarity of the doctoral studies. Other examples are Palacký university Olomouc (PUO, 2012) and cooperation of University of Hradec Králové (UHK), University of South Bohemia (USB), University of West Bohemia (UWB) and University of Ostrava (US) and their project Innovation of doctoral study program ICT in education (UHK, 2012).

\section{Conclusion}

Research results and university performance is currently very important topic in the Czech education and its possible transformation. If university/faculty wants to improve its performance, according to the literature, there are quite a lot of ways how to achieve it. This improvement is mainly focused on new courses profiling innovations, pedagogical/didactical innovations, process innovations, professionalization of teachers' innovations and education chain innovations.

OPPA project is focused on the innovation of the doctoral studies at the Faculty of Economics and Management, CULS Prague. The main project aims are to provide methodological workshops for PhD students, seminary for educators, induction weeks and launch Vademecum and Vibe platforms (both platforms have been launched in pilot version in November 2012). Each aim will lead to improvement of PhD students' performance.

It is unlikely that the result of the innovations will influence the same year in which the innovation was introduced. Following the literature (Gunday et al., 2011) we must assume that the difference between the year, in which the innovation was introduced, and the time when innovations can start influence might be two years. In our case two years of difference is suitable 
because the $R \& D$ results are always published with 2 years lag (RVVI 2010). We can expect similar lag in area of teachers and students training. According to Clotfelter et al. (2007), approaches to teaching and self-efficacy beliefs change slowly. It takes at least 1 year long training process until positive effects emerge. Shorter training seems to take teachers/educators more uncertain about themselves as teachers.

Evaluation of the project impact can be proved through new DEA models that can be calculated next years and will be based on the most up to date of R\&D results provided by RVVI.

\section{Acknowledgements}

We would like to thank to Dr. Lukáš Zagata for useful comments and suggestions that helped to improve our article.

This work was supported by the grant project of the Grant Agency of CULS Prague, No. 201221029, "Využití metody DEA pro alokaci veřejných zdrojů mezi produkční jednotky".

\section{References}

Abrami, P. C., Poulsen, C., Chambers, B. (2004) 'Teacher motivation to implement an educational innovation: Factors differentiating users and non-users of cooperative learning', Educational Psychology 24 (2), pp. 201-216. doi:10.1080/0144341 032000160146.

Angrist, J., Lavy, V. (2002) 'New evidence on classroom computers and pupil learning', Economic Journal 112, pp. 735-765. doi:10.1111/1468-0297.00068.

Atkinson, A., Burgess, S., Croxson, B., Gregg, P., Propper, C., Slater, H., et al. (2009) 'Evaluating the impact of performancerelated pay for teachers in England', Labour Economics 16, pp. 251-261. doi:10.1016/j.labeco.2008.10.003.
Buddin, R., Zamarro, G. (2009) 'Teacher qualifications and student achievement in urban elementary schools', Journal of Urban Economics 66, pp. 103-115. doi:10.1016/j.jue.2009.05.001. Call (2011) ‘Výzva pro prioritní osu 3 Modernizace počátečního vzdělávání, HLAVNÍ MĚSTO PRAHA. Operační program Praha - Adaptabilita [online]. 2011 [cit. 2012-11-13]. Avaivable: http://prahafondy.eu/userfiles/File/OPPA\%204\%20vyzva/ PO3_4_vyzva.pdf.

Clotfelter, C. T., Ladd, H. F., Vigdor, J. L. (2007) 'Teacher credentials and student achievement: Longitudinal analysis with student fixed effects', Economics of Education Review 26, pp. 673-682. doi:10.1016/j.econedurev.2007.10.002.

Commission of the European Communities. (2003) 'The role of the universities in the Europe of knowledge', Brussels 5-022003.

CULS (2012) 'Doktorské Studium/PhD studies' [online]. 2007 [cit. 2012-11-27]. Avaivable: http://www.czu.cz/cs/?r=335

CULS (2011). “Výroční zpráva o činnosti 2011/Rector's Report 2011", Avaivable: http://www.czu.cz/cs/?r=2933.

Drucker, P. F. (1985) 'Innovation and Entrepreneurship', Butterworth-Heinemann, Oxford.

FEM (2010). “Motivační Program pro Pracovníky a Doktorandy/ Motivation Programme for Academic Stuff and Ph.D. Students", Internal Document of the Faculty of Economics and Management.

FEM (2012) 'Doktorské Studium/PhD studies' [online]. 2007 [cit. 2012-11-27]. Avaivable: http://www.pef.czu.cz/en/?r=1024 
FI MUNI (2012) 'Projekt Inovace doktorského studia na Fakulte informatiky Masarykovy univerzity/Project of Innovation. of Doctoral study at the Faculty of Informatics at Masaryk University' [online]. 2008 [cit. 2012-12-19]. Avaivable: http://www.fi.muni.cz/studies/doctoral/oprojektu.xhtml.

FSS CU (2012) ‘novace doktorského studia na Fakultě sociálních věd Univerzity Karlovy v Praze/Innovation of doctoral study at the Faculty of Social Sciences at Charles University' [online]. 2010 [cit. 2012-12-19]. Avaivable: http://doktorand.fsv.cuni.cz/.

Fuchs, T., Woessmann, L. (2007) ‘What accounts for international differences in student performance? A re-examination using PISA data', Empirical Economics 32, pp. 433-464. doi:10.1007/ s00181-006-0087-0.

Gibbs, G., Coffey, M. (2004) 'The impact of training of university teachers on their teaching skills, their approach to teaching and the approach to learning of their students', Active Learning in Higher Education March 5, pp. 87-100. doi:10.1177/1469787404040463.

Gunday, G., Ulusov, G., Kilic, K., Alpkan, L. (2011) 'Effects of innovation types on firm performance', International Journal of Production Economics 133, pp. 662-676. doi:10.1016/j.ijpe.2011.05.014.

Haelermans, C., Blank, J. L. T. (2012) 'Is a schools' performance related to technical change?-A study on the relationship between innovations and secondary school productivity', Computers $\mathcal{E}$ Education 59, pp. 884-892. doi:10.1016/j.compedu.2012.03.027.

Haelermans, C., De Witte, K. (2012) 'The role of innovations in secondary school performance - Evidence from a conditional efficiency model', European Journal of Operational Research, vol. 223, pp. 541-549. doi:10.1016/j.ejor.2012.06.030.
Kingdom, G. G., Teal, F. (2006) ‘Does performance related pay for teachers improve student performance? Some evidence from India', Economics of Education Review 26, pp. 473-486. doi:10.1016/j.econedurev.2006.02.007.

Könings, K. D., Brand-Gruwel, S., van Merriënboer, J. G. (2007) 'Teachers' perspectives on innovations: Implications for educational design', Teaching and Teacher Education 23, pp. 985997. doi:10.1016/j.tate.2006.06.004.

Lavy, V. (2009) 'Performance Pay and Teachers' Effort, Productivity, and Grading Ethics', American Economic Review 99 (5), pp. 1979-2011. doi:10.1257/aer.99.5.1979.

Nii, L. J., Chin, A. (1996) 'Comparative trial of problem-based learning versus didactic lectures on clerkship performance', American Journal of Pharmaceutical Education 60, pp. 162-164.

OECD Oslo Manual (2005) 'Guidelines for collecting and interpreting technological innovation data', 3rd edition, Paris.

OPPA (2009) ‘Zaměření prioritníosy3-Modernizace počátečního vzdělávání, HLAVNÍ MĚSTO PRAHA. Operační program Praha - Adaptabilita [online]. 2009 [cit. 2012-11-13]. Avaivable: http://prahafondy.eu/cz/oppa/pro-prijemce/338_zamereniprioritni-osy-3---modernizace-pocatecniho-vzdelavani.html.

OPPA (2012) ‘Operační program Praha - Adaptabilita: Více důvodů cítit se tady jako doma', HLAVNÍ MĚSTO PRAHA. Operační program Praha - Adaptabilita [online]. 2012 [cit. 201211-13]. Avaivable: http://prahafondy.eu/cz/oppa.html.

Postareff, L., Lindblom-Ylänne, S., Nevgi, A. (2007) 'The effect of pedagogical training on teaching in higher education', Teaching and Teacher Education 23, pp. 557-571. doi:10.1016/j. tate.2006.11.013. 
PUO (2012) 'Inovace studia historických věd na Univerzitě Palackého/Study Innovations of Historical Sciences at Palacký University Olomouc' [online]. 2008 [cit. 2012-12-19]. Avaivable: http://esf.historie.upol.cz/.

Queen, S. (2009) 'Effect on cooperative learning and traditional strategies on academic performance in Middle school language arts, Wladen University, Mineapolis, Minnesota.

RVVI (2010) 'Metodika hodnocení výsledků výzkumných organizací/Methods for evaluating R\&D results', [Online], Available: http://www.vyzkum.cz [12 April 2012].

Scheel, H. (2000) "EMS: Efficiency Measurement System", [Online], Available: http://www.holger-scheel.de/ems/ [12 April 2012].

Staub, F. C. (2004) 'Transforming educational theory into usable knowledge: A case of co-constructing tools for lesson design and reflection', Quality in practice-oriented research in science education, pp. 41-52.

UHK (2012) 'Inovace doktorského studijního programu ICT ve vzdělávání/ Innovation of doctoral study program ICT in education' [online]. 2011 [cit. 2012-12-19]. Avaivable: http://www.osu.cz/index. php?kategorie $=915 \&$ id $=8479$.

Van Eekelen, I. M. (2005) 'Teachers' will and way to learn: Studies on how teachers learn and their willingness to do so', Unpublished doctoral dissertation, Maastricht University. 